\title{
ANALISA IMPLEMENTASI E-SCM PADA MODEL BISNIS DISTRIBUTION OUTLET (DISTRO)
}

\author{
I Dewa Made Adi Baskara Joni \\ STMIK STIKOM Indonesia \\ dewadi@stiki-indonesia.ac.id
}

\begin{abstract}
Abstrak
Distribution outlet (distro) merupakan salah satu jenis UMKM yang ada di Indonesia. Dalam pengelolaannya dari proses pengadaan bahan baku, produksi sampai transaksi penjualan umumnya masih menggunakan sistem konvensional. Sistem konvensional tersebut menyebabkan pengelola distro tidak dapat memonitor secara real time pergerakan omset penjualannya. Penelitian ini dimulai dengan pengumpulan data primer dan sekunder. Data yang telah dikumpulkan dianalisis, kemudian dilakukan implementasi menggunakan dua perangkat lunak. Perangkat lunak yang digunakan dalam implementasi adalah www.erzap.com (ERZAP) oleh Z4Comp.com dan www.tradegecko.com (TRADEGECKO) oleh TradeGecko Pte. Ltd. Dua perangkat lunak tersebut diuji dan dianalisis terkait ketersediaan fitur-fitur dasar dalam implementasi e-SCM. Hasil penelitian menunjukkan bahwa sistem konvensional yang berjalan saat ini pada usaha distro hanya cukup untuk menangani transaksi dalam skala regional saja. Dengan mengimplementasikan suatu sistem e-SCM diharapkan dapat meningkatkan efisiensi produksi dan mengefektifkan distribusi barangnya. E-SCM dapat mengintegrasikan keseluruhan data pengelolaan distro terkait dengan manajemen rantai pasokan mulai dari hulu sampai hilir. Terdapat beberapa elemen supply chain yang tidak dimiliki oleh kedua sistem. Seperti misalnya elemen planning yang tidak ada pada ERZAP dan elemen planning dan production tidak ada pada TRADEGECKO.
\end{abstract}

Kata kunci: supply, chain, management, distro, UMKM

\begin{abstract}
Distribution outlet (distro) is one type of MSMEs in Indonesia. In its management from raw materials procurement process, production until general sales transaction still use conventional system. The conventional system causes distro managers can not monitor in real time the movement of sales turnover. This research starts with primary and secondary data collection. The data that have been collected is analyzed, then implemented using two software. The software used in the implementation is www.erzap.com (ERZAP) by Z4Comp.com and www.tradegecko.com (TRADEGECKO) by TradeGecko Pte. Ltd. The two software are tested and analyzed regarding the availability of basic features in the implementation of e-SCM. The results show that the current conventional system in the distro is only sufficient to handle transactions on a regional scale only. Implementing an e-SCM system is expected to improve production efficiency and streamline the distribution of its goods. ESCM can integrate the overall distro data management associated with supply chain management from upstream to downstream. There are several supply chain elements that are not owned by both systems. Such as planning elements that do not exist in ERZAP and planning and production elements are not in TRADEGECKO.
\end{abstract}

Keywords : supply, chain, management, distro, MSMEs

\section{PENDAHULUAN}

Ekonomi nasional saat ini banyak didorong oleh kontribusi industri kreatif dengan melibatkan banyak generasi muda yang memiliki kreativitas dan inovasi yang berorientasi pada Usaha Kecil dan Menengah (UKM) (Abdurofiq, 2014). Dalam istilah lain UKM juga disebut sebagai Usaha Mikro, Kecil dan Menengah (UMKM). UMKM merupakan usaha yang memiliki jumlah maupun pangsa yang mayoritas jika dibandingkan dengan Usaha Besar (UB). Data terakhir yang didapatkan dari website resmi Kementrian Koperasi dan Usaha Kecil Menengah Republik Indonesia (KEMENKOP UKM RI) menguatkan fakta tersebut. Pada tahun 2011-2012 perkembangan UMKM di Indonesia mencapai 1.328.147 unit dengan pangsa 
meningkat sebesar $2,41 \%$. Untuk UB perkembangannya hanya mencapai angka 16 unit dengan pangsa $0.32 \%$ meningkat. Hal tersebut juga terjadi pada tahun 20122013, perkembangan UMKM mencapai 1.361.129 unit dengan pangsa konsisten meningkat sebesar 2,41\%. Untuk UB mengalami perkembangan yang cukup baik jika dibandingkan dengan tahun sebelumnya yaitu sebanyak 98 unit dengan pangsa 1,97\% (KEMENKOP UKM RI, 2012, 2013).

Jika ditinjau dari sisi produk yang dihasilkan, UMKM lebih sederhana dalam proses produksinya jika dibandingkan dengan UB. Namun jika dilihat dari beragamnya jenis UMKM yang ada dan jumlah yang sangat besar tentu dapat menjadi potensi ekonomi yang kuat bagi Indonesia. Distribution outlet (distro) merupakan salah satu jenis UMKM yang ada di Indonesia. Dewasa ini, distro sangat berkembang di Bali. Hal tersebut terbukti dengan banyaknya distro yang ada baik di Denpasar maupun daerah lainnya seperti Badung, Gianyar, Tabanan, Singaraja dan lain sebagainya. Distro tersebut menjual produk fashion yang diproduksi sendiri maupun titipan (konsinyasi) dari merek distro lainnya. Dalam pengelolaannya dari proses pengadaan bahan baku, produksi sampai transaksi penjualan umumnya masih menggunakan sistem konvensional. Dalam hal pemasaran, beberapa distro sudah menggunakan media sosial namun belum terintegrasi dengan sistem stok dan penjualan. Sistem konvensional tersebut mengakibatkan pengelola distro tidak dapat memonitor secara real time pergerakan omset penjualannya. Catatan manual dari pengadaan barang, penjualan dan pemasaran cukup sulit untuk diproses menjadi laporan yang dibutuhkan dalam menentukan strategi pengembangan usaha.

Sistem konvensional yang berjalan saat ini pada usaha distro, hanya cukup untuk menangani transaksi dalam skala regional saja. Ketika masuk pada pasar nasional apalagi internasional, sistem tersebut tidak akan dapat mengelola proses bisnis agar dapat berjalan dengan baik. Dibutuhkan suatu sistem yang dapat mengelola sistem produksi dari hulu sampai hilir. Dari proses pengadaan barang (hulu) haruslah terdata dengan akurat dan cepat. Perubahan rantai nilainya (value chain) harus tercatat di dalam sistem mulai dari bahan baku sampai produk siap jual. Pada proses distribusi barang (produk) kepada pelanggan (hilir) harus dapat se-efisien mungkin sehingga harga produk memiliki daya saing di pasaran. Electronic Supply Chain Management (e-SCM) merupakan sistem yang dapat menjadi solusi dari permasalahan tersebut. E-SCM adalah kombinasi antara internet dengan supply chain management dan keseimbangan diantara keduanya. Tujuan dari e-SCM adalah untuk menggabungkan kegiatan di di dalam organisasi untuk memberikan nilai pelanggan (customer value). Rantai pasokan terintegrasi tersebut melibatkan koordinasi dan pembagian informasi di antara semua pemangku kepentingan untuk mendapatkan manfaat utama dari rantai pasokan terintegrasi yang mengarah pada peluang untuk keunggulan kompetitif (PulevskaIvanovska \& Kaleshovska, 2013). Dengan mengimplementasikan suatu sistem eSCM diharapkan dapat meningkatkan efisiensi produksi distro dan mengefektifkan distribusi barangnya. ESCM dapat mengintegrasikan keseluruhan data pengelolaan distro terkait dengan manajemen rantai pasokan mulai dari hulu sampai hilir.

\section{METODE}

Data dalam penelitian ini menggunakan data primer dan sekunder. Teknik pengumpulan data primer yang digunakan adalah observasi dan wawancara. Data sekunder yang dikumpulkan menggunakan teknik dokumentasi dan studi pustaka. Berdasarkan data tersebut, dilakukan analisis dengan mengkaji permasalahan pengelolaan distro. Permasalahan akan difokuskan pada pengelolaan rantai pasok. Selanjutnya akan dilakukan implementasi dua buah perangkat lunak yang dapat digunakan untuk pengelolaan rantai pasok distro. Dari hasil implementasi kedua perangkat lunak 
tersebut akan dibandingkan dari sisi fitur dasar yang dibutuhkan dalam pengelolaan rantai pasok. Penelitian ini akan menghasilkan kajian penerapan solusi eSCM terhadap model usaha distro.

\section{HASIL DAN PEMBAHASAN}

Hasil observasi menunjukkan bahwa perkembangan usaha distro dewasa ini terus meningkat. Hal tersebut dapat dibuktikan dengan semakin menjamurnya outlet dan beberapa merek (brand) distro lokal telah dipasarkan pada department store maupun mal perbelanjaan. Wilayah outlet tersebut tidak hanya mencakup kota besar seperti Denpasar atau wilayah Kuta. Perkembangannya sudah sampai wilayah Gianyar, Tabanan maupun pelosok Badung lainnya. Kegiatan tahunan Paradise Island Clothing Association (PICA) festival juga digelar rutin untuk memasarkan merek-merek lokal dan disambut antusias oleh masyarakat. Data hasil wawancara juga menguatkan bahwa usaha distro saat ini tidak dapat dipandang sebelah mata. Usaha distro menjanjikan keuntungan yang besar karena perputaran produk dari proses produksi, pemasaran sampai terjual pada end-user relatif cepat. Dari hasil observasi didapatkan juga bahwa kebanyakan Distro telah menggunakan sistem berbasis komputer. Namun sistem berbasis komputer tersebut lebih kepada pencatatan penjualan saja (point of sales). Untuk pengelolaan sistem pergudangan, manajemen pemasok, pengontrolan stok, manajemen dan penjadwalan produksi belum menggunakan sistem berbasis komputer. Fokus pengelola ada pada proses penjualan. Tidak terdapat pengolahan data apalagi analisis terkait pengelolaan stok dengan proses penjualan. Disetiap distro yang menjadi kios penjualan juga terdapat barangbarang atau produk titipan. Jadi tidak hanya satu merek atau brand utama yg diproduksi distro tersebut saja yang dijual, terdapat juga brand distro lainnya dengan sistem konsinyasi. Pencatatan data barang dan data penjualan konsinyasi masih dilakukan dalam buku catatan manual. Data sekunder yang dikumpulkan menggunakan teknik dokumentasi dan studi pustaka. Data dokumentasi yang didapatkan adalah berupa foto keadaan distro dan kegiatan pengelolaan barang. Data berupa dokumen penjualan, nota, buku pengelolaan barang juga menjadi data dokumentasi yang digunakan. Dari hasil olah data dokumentasi dan studi pustaka didapatkan informasi dan pengetahuan mengenai penerapan supply chain management pada UMKM. Informasi mengenai perangkat lunak yang dapat diimplementasikan juga menjadi hasil dari studi pustaka. Perangkat lunak yang dapat diterapkan adalah www.erzap.com oleh Z4Comp.com dan www.tradegecko.com oleh TradeGecko Pte. Ltd. Pemilihan perangkat lunak tersebut berdasarkan fitur yang ditawarkan memenuhi kebutuhan dalam penerapan eSCM. Selain itu, dalam hal pemasaran dan penjualan kedua perangkat lunak tersebut juga memiliki fitur yang dibutuhkan karena berbasis Web dan dapat diakses melalui jaringan internet. Dengan pengenalan serta pemasaran melalui internet setidaknya dapat menarik minat masyarakat, karena informasi ditampilkan bukan hanya sekedar teks biasa melainkan perpaduan teks, gambar, dan video atau dapat juga disebut dengan web (Setyawan \& Marti, 2013).

$$
\text { Setelah melalui tahapan }
$$

pengumpulan dan analisis data.

Selanjutnya dilakukan analisis permasalahan. Dari hasil analisis permasalahan, didapatkan informasi bahwa usaha distro adalah termasuk jenis usaha dagang. Untuk distro yang memproduksi brand clothing tersendiri sekaligus menjadi jenis usaha manufaktur. Permasalahan utama yang dialami adalah pada aliran rantai pasok mulai dari pengelolaan bahan baku (pemasok) sampai pada penjualan ditingkat retail kepada pelanggan akhir. Permasalahan yang muncul seperti kekurangan atau kelebihan stok, produksi yang tidak sesuai jadwal sampai pada distribusi produk yang terhambat pada outlet yang ada. Berdasarkan hasil penelitian menurut (Sorak \& Dragic, 2013), pendekatan tradisional terhadap pengelolaan UMKM dikaitkan dengan penyediaan kapasitas yang berlebihan sebagai perlindungan 
terhadap variabilitas permintaan. Karena kemungkinan perubahan cepat dan besar di pasar, pendekatan ini menghadirkan resiko besar dengan potensi efek samping. Respon yang cepat terhadap variabilitas permintaan memerlukan solusi yang efisien untuk semua elemen yang membentuk rantai pasokan seperti: demand management (pengelolaan permintaan), planning (perencanaan), procurement (pengadaan), warehousing (pergudangan), production (produksi) dan transport \& distribution (transportasi \&

Tabel 1. Perbandingan Elemen Supply Chain

\begin{tabular}{lcc|c}
\multicolumn{2}{c}{ Tabel 1. Perbandingan Elemen Supply Chain } \\
\cline { 2 - 4 } Elemen Supply Chain & \multicolumn{2}{c}{ Sistem e-SCM } \\
\cline { 2 - 4 } & ERZAP & TRADEGECKO \\
\hline Demand Management & $\sqrt{ }$ & $\sqrt{ }$ \\
\hline Planning & - & - \\
\hline Procurement & $\sqrt{ }$ & $\sqrt{ }$ \\
\hline Warehousing & $\sqrt{ }$ & - \\
\hline Production & $\sqrt{ }$ & $\sqrt{ }$ \\
\hline Transport \& Distribution & $\sqrt{ }$ & ( \\
\hline
\end{tabular}

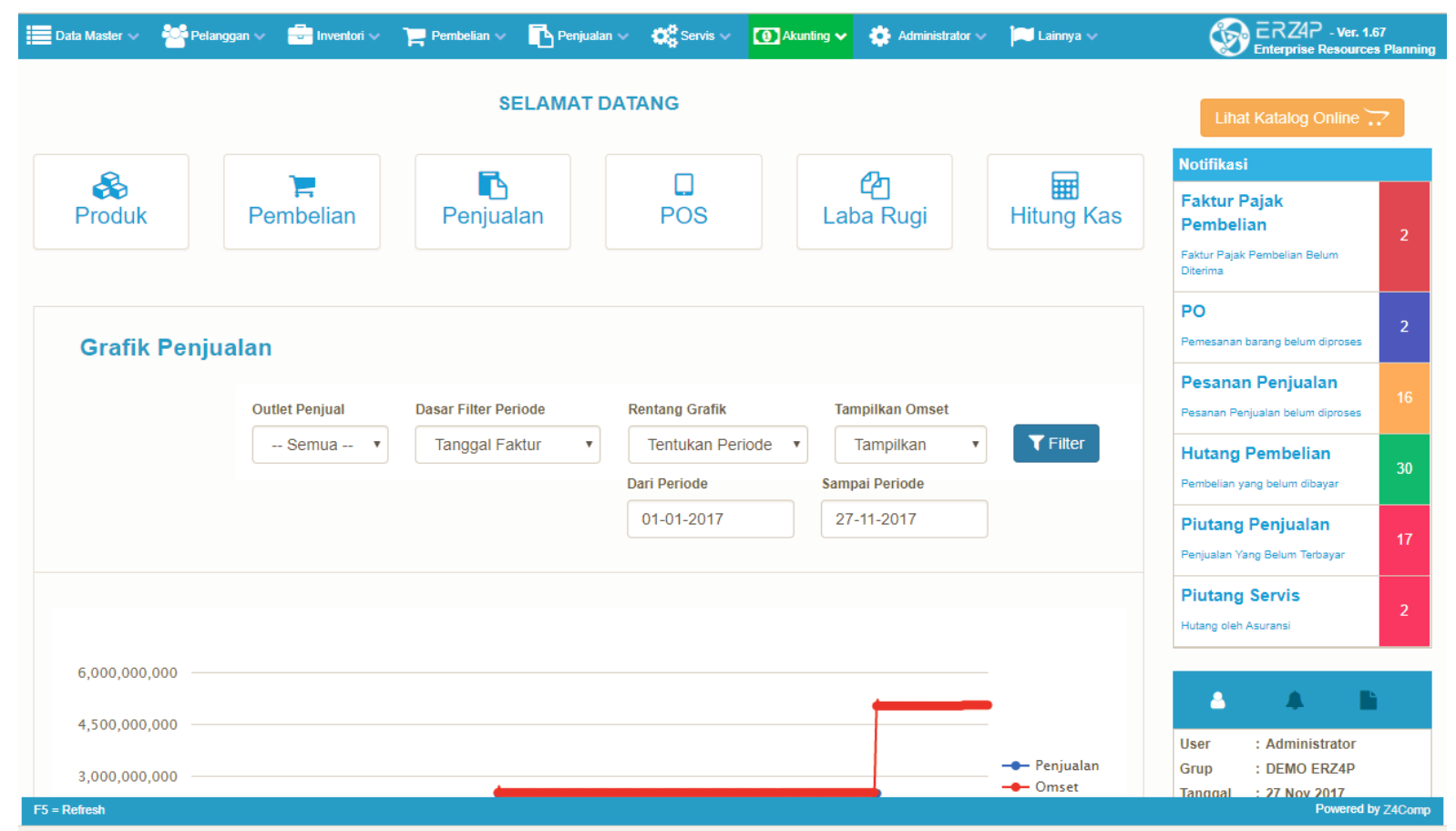

Gambar 1. Tampilan Dashboard ERZAP distribusi) (Sorak \& Dragic, 2013). Dalam penelitian ini dilakukan kajian elemen supply chain (SC) yang dapat diimplementasikan dengan dua sistem yaitu: www.erzap.com (ERZAP) dan www.tradegecko.com (TRADEGECKO). Tampilan sistem ERZAP dan TRADEGECKO dapat dilihat pada gambar 1 dan gambar 2. Perbandingan elemen supply chain terhadap kedua sistem tersebut dapat dilihat pada tabel 1. 


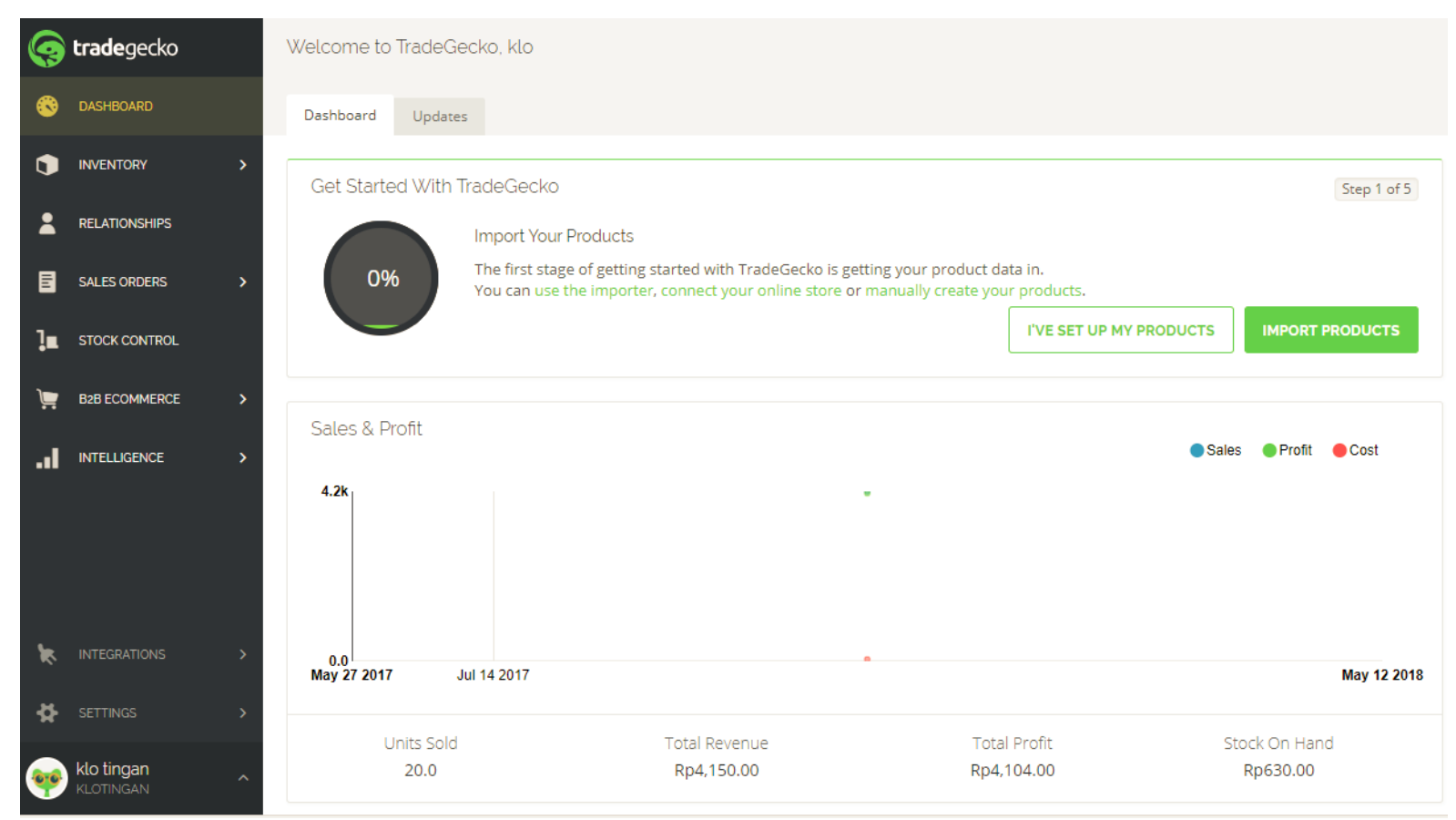

Gambar 2. Tampilan Dashboard TRADEGECKO

Pada gambar 1 dapat dilihat tampilan dashboard dari ERZAP. Pada gambar tersebut dapat dilihat menu-menu yang dapat diakses dengan hak akses super admin. Untuk menunjang kajian dalam penelitian ini, menu yang difokuskan adalah pada menu Data Master, Pembelian dan Penjualan. Pada gambar 2 dapat dilihat tampilan dashboard dari TRADEGECKO. Dalam penelitian ini kajian difokuskan pada keseluruhan menu kecuali menu Intelligence yang memuat fitur-fitur yang mengarah pada Business Intelligence.

Pada tabel 1 dapat dilihat elemen dalam supply chain yang dapat ditangani pada fitur-fitur yang disediakan ERZAP dan TRADEGECKO. Pada dasarnya baik ERZAP maupun TRADEGECKO merupakan suatu enterprise system yang dapat digunakan oleh berbagai jenis perusahaan. ERZAP dan TRADEGECKO merupakan penyedia layanan Software as a Service (SaaS), jadi pelanggan yang menggunakan jasanya tidak perlu membeli software namun cukup membayar jasa layanan sesuai dengan ketentuan. Jika ditinjau lebih mendalam, ERZAP merupakan Enterprise Resource Planning (ERP) dan TRADEGECKO merupakan Inventory Management System (IMS). Dalam penelitian ini, fiturfitur yang ada pada kedua sistem tersebut difokuskan pada kajian Supply Chain Management. Dapat dilihat pada tabel 1 bahwa terdapat beberapa elemen supply chain yang tidak dimiliki oleh kedua sistem. Seperti misalnya elemen planning yang tidak ada pada ERZAP dan elemen planning dan production tidak ada pada TRADEGECKO.

Penelitian ini mencoba mengkaji penerapan supply chain management pada model bisnis distro. Berdasarkan pemaparan perbandingan elemen supply chain dengan ERZAP dan TRADEGECKO pada tabel 1 diatas, dilakukan analisis fungsionalitas sistem. Untuk dapat lebih mudah memahami fitur (fungsionalitas) dari sistem digambarkan dalam use case diagram. Use case diagram tersebut dapat dilihat pada pada gambar 3 berikut. 


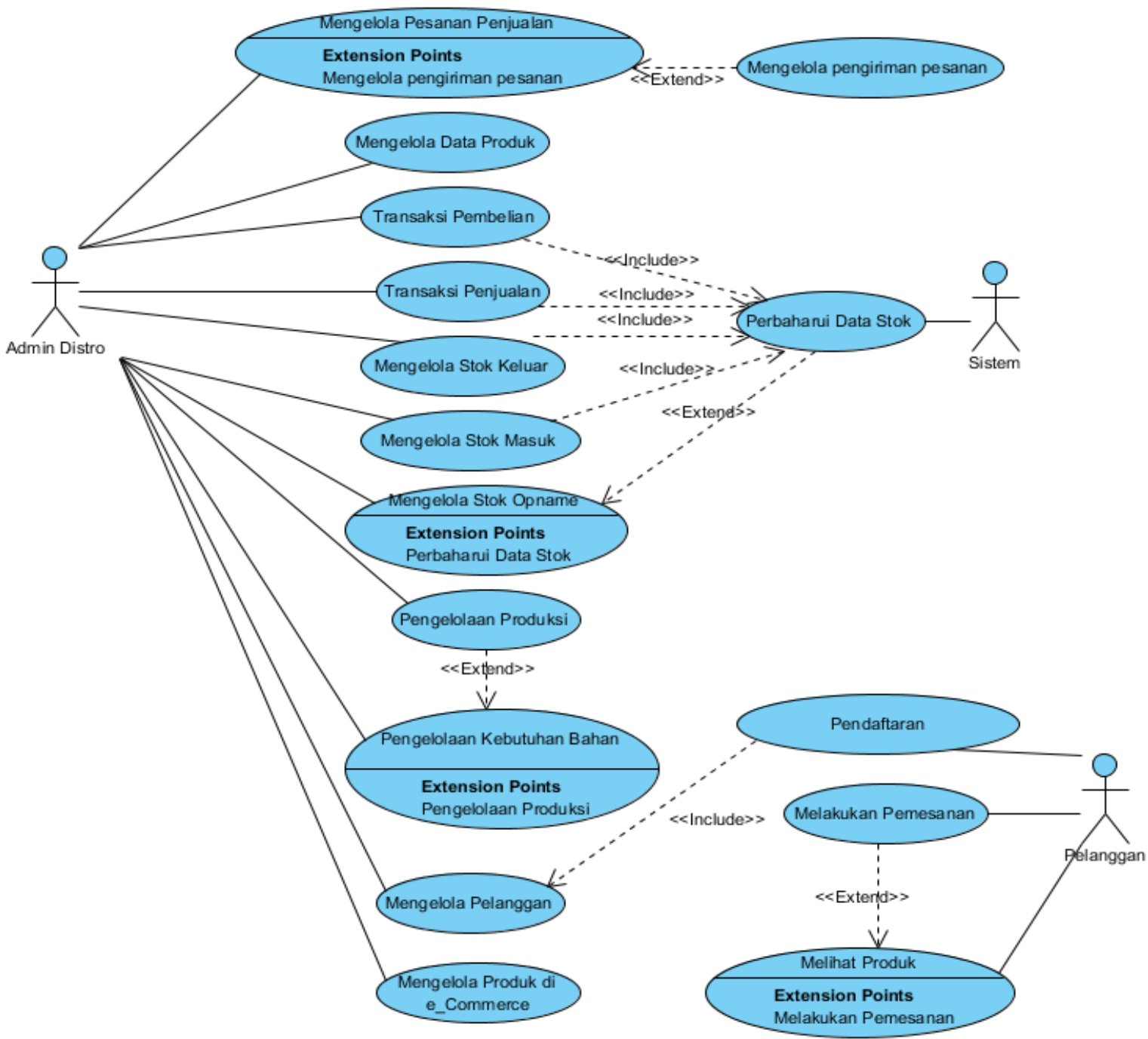

Gambar 3. Use Case Diagram e-SCM

Pada gambar 1 dapat dilihat fitur-fitur atau fungsionalitas dari e-SCM yang diadaptasi dari sistem ERZAP dan TRADEGECKO. Penggambaran Use Case Diagram merupakan hasil analisa dan sintesis permasalahan yang dikaji. Fitur yang dibahas merupakan fitur yang dikaitkan dengan kebutuhan sistem dalam hal ini e-SCM. Dapat dilihat pada gambar 3 diatas terdapat use case (fungsionalitas) dan aktor-aktor yang terlibat. Aktor dan asosiasinya dengan use case adalah sebagai berikut:

1. Aktor Admin Distro:
a. Mengelola Pesanan Penjualan extend Mengelola Pengiriman Pesanan
b. Mengelola Data Produk
c. Transaksi Pembelian
d. Transaksi Penjualan
e. Mengelola Stok Keluar

f. Mengelola Stok Masuk

g. Mengelola Stok Opname extend Perbaharui Data Stok

h. Pengelolaan Produksi extend Pengelolaan Kebutuhan Bahan

i. Mengelola Pelanggan

j. Mengelola Produk di e-Commerce

2. Aktor Pelanggan:
a. Pendaftaran
b. Melakukan Pemesanan
c. Melihat Produk

3. Aktor Sistem: Perbaharui Data Stok Pemaparan aktor dan use case diatas adalah menjelaskan fungsionalitas yang dapat dilakukan masing-masing aktor. Untuk lebih jelasnya fungsi dari masing-masing use case pada Use Case Diagram diatas dapat dilihat pada tabel 2 berikut. 
Tabel 2. Use Case dan Fungsinya

\begin{tabular}{|c|c|}
\hline Use Case & Fungsi \\
\hline Mengelola Pesanan Penjualan & $\begin{array}{l}\text { Mengelola data pemesanan produk yang akan } \\
\text { didistribusikan }\end{array}$ \\
\hline $\begin{array}{l}\text { Mengelola Pengiriman } \\
\text { Pesanan }\end{array}$ & $\begin{array}{l}\text { Mengelola pengiriman yang dapat diambil ditempat } \\
\text { atau dikirim melalui jasa ekspedisi }\end{array}$ \\
\hline Mengelola Data Produk & Mengelola master data produk \\
\hline Transaksi Pembelian & Memproses transaksi pembelian kepada pemasok \\
\hline Transaksi Penjualan & Memproses transaksi penjualan kepada pelanggan \\
\hline Mengelola Stok Keluar & Mengelola data produk yang keluar dari gudang \\
\hline Mengelola Stok Masuk & Mengelola data produk yang masuk ke gudang \\
\hline Mengelola Stok Opname & $\begin{array}{l}\text { Memproses penyesuaian stok sistem dengan stok } \\
\text { aktual di gudang }\end{array}$ \\
\hline Perbaharui Data Stok & Sistem melakukan penyesuaian data stok \\
\hline Pengelolaan Produksi & Mengelola data produksi yang akan dilakukan \\
\hline $\begin{array}{l}\text { Pengelolaan Kebutuhan } \\
\text { Bahan }\end{array}$ & $\begin{array}{l}\text { Mengelola data bahan baku material produksi (bill of } \\
\text { material) }\end{array}$ \\
\hline Mengelola Pelanggan & Mengelola master data pelanggan \\
\hline Pendaftaran & Proses pendaftaran pelanggan baru \\
\hline $\begin{array}{l}\text { Mengelola Produk e- } \\
\text { Commerce }\end{array}$ & $\begin{array}{l}\text { Mengelola data produk yang akan dipasarkan } \\
\text { melalui sistem e-Commerce }\end{array}$ \\
\hline Melihat Produk & Melihat produk yang tersedia pada e-Commerce \\
\hline Melakukan Pen & $\begin{array}{l}\text { Proses pemesanan produk yang diinginkan melalui } \\
\text { sistem e-Commerce }\end{array}$ \\
\hline
\end{tabular}

Pada tabel 2 di atas dapat dilihat bahwa setiap use case memiliki fungsi yang berbeda-beda. Fungsi tersebut disesuaikan berdasarkan kebutuhan dalam implementasi Supply Chain Management. Keseluruhan fungsi yang dijelaskan di atas merupakan hasil analisa terhadap fitur-fitur yang terdapat pada ERZAP dan TRADEGECKO.
Penggambaran fungsionalitas sistem dalam Use Case Diagram bertujuan agar dapat memahami dengan jelas fitur-fitur yang akan dibahas dan dikaitkan dengan elemen-elemen pada Supply Chain. Elemen supply chain yang dilingkupi pada fitur-fitur sistem yang telah digambarkan pada Use Case Diagram dapat dilihat pada tabel 3.

Tabel 3. Elemen Supply Chain dengan Use Case

\begin{tabular}{ll}
\hline \multicolumn{1}{c}{ Elemen SC } & \multicolumn{1}{c}{ Use Case } \\
\hline Demand Management & $\begin{array}{l}\text { pendaftaran, mengelola pelanggan, mengelola produk } \\
\text { e-Commerce, transaksi penjualan, melihat produk, } \\
\text { melakukan pemesanan }\end{array}$ \\
\hline Planning & \multicolumn{1}{c}{-} \\
\hline Procurement & transaksi pembelian, perbaharui data stok \\
\hline Warehousing & $\begin{array}{l}\text { mengelola stok masuk, mengelola stok keluar, } \\
\text { mengelola stok opname }\end{array}$ \\
\hline Production & pengelolaan produksi, pengelolaan kebutuhan bahan \\
\hline Transport \& & $\begin{array}{l}\text { mengelola pesanan penjualan, mengelola pengiriman } \\
\text { Distribution }\end{array}$ \\
\hline
\end{tabular}


Pada elemen Demand Management, proses dimulai dari ketika calon pelanggan mulai menjadi bagian dari sistem dengan melakukan pendaftaran. Proses tersebut digambarkan pada use case "Pendaftaran". Admin distro juga dapat melakukan secara langsung dengan menjalankan fitur "Mengelola Pelanggan". Proses pengelolaan pelanggan ini juga bertujuan untuk mengelola pelanggan bisnis (toko retail, re-seller dan lain sebagainya) maupun pelanggan yang sebagai end-user. Use Case "Mengelola Produk e-Commerce" juga menjadi bagian dari elemen ini karena pada fitur ini dapat ditentukan produk yang mana saja akan dipasarkan melalui channel B2B commerce. Pelanggan bisnis dari distro dapat mengakses informasi produk dan langsung melakukan pemesanan melalui fitur e-Commerce yang telah disediakan secara private. Use Case "Transaksi Penjualan" merupakan fitur yang digunakan untuk mencatat data transaksi yang dilakukan kepada pelanggan enduser yang datang langsung ke distro. Pada use case "Melihat Produk" yang dirancang extend terhadap use case "Melakukan Pemesanan", menjelaskan tentang transaksi melalui channel B2B commerce yang telah disampaikan di atas. Pada proses ini pelanggan yang telah terdaftar dapat melihat produk-produk yang dipasarkan melalui e-Commerce. Jika terdapat produk yang sesuai dapat langsung melakukan pemesanan.

Pada ERZAP dan TRADEGECKO tidak terdapat fitur yang membahas elemen planning. Planning (perencanaan) mengacu pada proses menentukan apa yang harus dilakukan dan bagaimana melakukannya. Perencanaan terjadi dibanyak tingkatan, dari keputusan seharihari yang dibuat oleh individu dan keluarga, hingga keputusan kompleks yang dibuat oleh bisnis dan pemerintah. (Litman, 2013). Elemen planning merupakan bagian yang penting dalam suatu sistem Supply Chain Management. Hal tersebut menjadi kunci dalam memastikan kapasitas produksi yang tepat maupun siklus distribusi barang dalam jaringan rantai pasok. Dengan elemen planning akan didapatkan penyediaan bahan baku maupun produk jadi yang sesuai dengan kebutuhan.

Elemen procurement dibahas pada use case "Transaksi Pembelian" dan "Perbaharui Data Stok". Pada use case "Transaksi Pembelian" adalah proses pencatatan transaksi pengadaan barang yang dilakukan kepada pemasok. Setiap transaksi pembelian baik bahan baku maupun bahan setengah jadi akan dicatat melalui fitur ini. Ketika transaksi pembelian telah berhasil dilakukan, secara otomatis sistem akan melakukan pembaharuan data stok melalui use case "Perbaharui Data Stok". Sistem akan memastikan stok memiliki data aktual berdasarkan proses dalam transaksi pembelian tersebut.

Elemen warehousing dalam penelitian ini dibahas pada use case "Mengelola Stok Masuk", "Mengelola Stok Keluar" dan "Mengelola Stok Opname". Use Case "Mengelola Stok Masuk" merupakan suatu fitur yang mencatat data penempatan barang pada outlet yang diinginkan maupun gudang yang tersedia. Pada fitur ini juga membahas asal barang (pemasok maupun outlet). Use Case "Mengelola Stok Keluar" merupakan kebalikan dari use case sebelumnya. Pada fitur ini akan mencatat tempat outlet dan gudang barang yang dikeluarkan. Selain itu jika ada, beban yang dikeluarkan seperti beban transportasi maupun operasioal dapat ditambahkan. Use Case "Mengelola Stok Opname" (SO) adalah fitur yang membahas penyesuaian stok aktual di gudang dengan stok yang tersimpan di sistem. Pada fitur ini terdapat 3 sub proses diantaranya adalah: buat formulir SO, pengisian hasil SO dan koreksi hasil SO. Proses "buat formulir SO" adalah untuk mempersiapkan dokumen yang dibutuhkan ketika harus mengecek jumlah stok aktual yang ada di gudang. Pada proses ini formulir akan di cetak berdasarkan gudang maupun barang yang ingin dicek. Setelah pengecekan, selanjutnya dapat dilakukan "pengisian hasil SO". Pada proses ini akan diisi hasil stock opname untuk setiap barang ke dalam sistem berdasarkan data pada dokumen stock opname yang telah dibuat. Jika terdapat kekeliruan pada proses pencatatan stock opname, proses 
"koreksi hasil SO" dapat dilakukan. Pada proses ini, pada setiap gudang akan ditampilkan data hasil stock opname dan dapat dikoreksi dengan menginputkan data koreksi yang diinginkan. Untuk use case "Mengelola Stok Masuk" dan "Mengelola Stok Keluar" include terhadap use case "Perbaharui Data Stok". Hal tersebut menjelaskan bahwa use case "Perbaharui Data Stok" memperluas perilaku use case "Mengelola Stok Masuk" dan "Mengelola Stok Keluar". Ketika admin distro menjalankan fitur "Mengelola Stok Masuk" maupun "Mengelola Stok Keluar", maka sistem akan otomatis "Perbaharui Data Stok". Untuk use case "Mengelola Stok Opname" extend terhadap use case "Perbaharui Data Stok". Hal tersebut menjelaskan bahwa use case "Perbaharui Data Stok" memperluas perilaku "Mengelola Stok Opname" namun tidak wajib. Ketika admin distro menjalankan fitur "Mengelola Stok Opname" jika terjadi penyesuaian stok aktual dengan stok sistem maka akan menjalankan "Perbaharui Data Stok", jika tidak ada penyesuaian maka tidak akan dijalankan.

Elemen production dibahas pada use case "Pengelolaan Kebutuhan Bahan" dan "Pengelolaan Produksi". Use case "Pengelolaan Kebutuhan Bahan" adalah suatu fitur yang digunakan untuk membuat formula/ komposisi/ bill of material (BOM). Pada fitur ini akan dikelola data daftar bahan, beban/biaya produksi, dan hasil produksi. BOM dapat dibuat untuk mengelola setiap produk atau item yang akan diproduksi distro. Use case "Pengelolaan Produksi" adalah suatu fitur yang disediakan untuk mengelola produk yang akan diproduksi oleh distro. Data yang dikelola adalah tanggal produksi, penanggung jawab produksi, gudang penyimpanan hasil produksi dan data BOM yang digunakan untuk produksi. Use case diagram pada gambar 3 menggambarkan bahwa use case "Pengelolaan Kebutuhan Bahan" extend terhadap use case "Pengelolaan Produksi". Hal tersebut dimaksudkan bahwa use case "Pengelolaan Produksi" memperluas perilaku use case "Pengelolaan Kebutuhan Bahan" namun tidak wajib. Ketika dilakukan proses mengelola kebutuhan bahan (BOM), admin distro bertujuan untuk mencatat formula atau komposisi bahan. Jika BOM tersebut dilanjutkan ke tahap produksi, pada saat itu admin distro akan menjalankan pengelolaan produksi. Jika BOM tidak dilanjutkan ke tahap produksi, maka fitur pengelolaan produksi tidak akan dijalankan. Fitur pengelolaan produksi ini bertujuan untuk mencatat keseluruhan proses produksi yang ada di distro. Dengan mencatat keseluruhan proses produksi, didapatkan data yang akurat mengenai setiap produk yang ada di gudang mulai dari bahan yang digunakan sampai biaya yang dibutuhkan dalam proses produksinya.

Elemen transport \& distribution dibahas pada use case "Mengelola Pesanan Penjualan" dan "Mengelola Pengiriman Pesanan". Use case "Mengelola Pesanan Penjualan" membahas mengenai proses pemesanan produk oleh pelanggan. Pemesanan produk yang dimaksud adalah untuk pelanggan bisnis dimana data pelanggan tersebut telah terdaftar terlebih dahulu. Pada fitur mengelola pesanan penjualan, data yang diinputkan mulai dari tanggal pemesanan, outlet tempat barang dipesan, sales yang melakukan penjualan, pelanggan yang melakukan pemesanan, prioritas pesanan dan status pesanan (ambil ditempat atau dikirim). Use case "Mengelola Pesanan Penjualan" extend terhadap use case "Mengelola Pengiriman Pesanan". Hal tersebut dapat diartikan bahwa use case "Mengelola Pesanan Penjualan" memperluas perilaku use case "Mengelola Pengiriman Pesanan" namun tidak wajib. Ketika data pesanan penjualan pada kolom status pesanan diisi "barang diambil ditempat", maka use case "Mengelola Pengiriman Pesanan" tidak dijalankan. Hal tersebut dapat diartikan bahwa pelanggan akan mengambil barang yang dipesan secara langsung, jadi tidak diperlukan data mengenai alamat pengiriman. Jika data pesanan penjualan pada kolom status pesanan diisi "barang dikirim", maka data mengenai jasa ekspedisi, perkiraan tanggal pengiriman , 
alamat pengiriman dan ongkos kirim harus diinputkan.

Penelitian ini melakukan analisa terhadap permasalahan pengelolaan rantai pasok (supply chain management) pada model bisnis distro. Dari data yang dikumpulkan kemudian dilakukan pengolahan, dihasilkan informasi tentang perkembangan model bisnis distro. Seiring dengan perkembangan tersebut, muncul berbagai permasalahan. Permasalahan yang terjadi mulai dari pengelolaan hulu sampai hilir dalam rantai pasok.

Pada proses produksinya, distro tidak memproduksi dalam jumlah banyak untuk setiap item barang. Namun, variasi item dan jenis barang cukup banyak untuk dikelola. Hal tersebut menyebabkan setiap item barang akan membutuhkan bahan dan pemrosesan yang berbeda-beda. Hal ini yang menimbulkan permasalahan pengelolaan hulu pada rantai pasok. Para pemasok tidak mendapatkan informasi yang baik mengenai kebutuhan barang maupun bahan dari distro. Pihak distro juga tidak memiliki informasi mengenai ketersediaan bahan maupun barang yang dibutuhkan. Informasi mengenai kapan bahan atau barang akan dikirim dan sampai juga menjadi permasalahan.

Semua permasalahan tersebut dapat diatasi dengan menerapkan suatu sistem Electronic Supply Chain Management (eSCM). Fitur-fitur yang tersedia seperti "Transaksi Pembelian" dan "Perbaharui Data Stok" dapat digunakan dalam menjalankan elemen procurement pada supply chain. Ketika bahan maupun barang telah sampai untuk disimpan di gudang dapat menjalankan fitur "Mengelola Stok Masuk", "Mengelola Stok Keluar" dan "Mengelola Stok Opname". Hal tersebut untuk dapat menjalankan elemen warehousing pada supply chain. Ketika setiap bahan telah siap untuk dilakukan proses produksi, maka dapat menjalankan elemen production. Pada elemen ini terlebih dahulu harus dibuatkan formula atau komposisi dari setiap produk yang dibahas pada use case atau fitur "Pengelolaan Kebutuhan Bahan". Selanjutnya dapat langsung dikelola setiap melakukan proses produksi pada use case atau fitur "Pengelolaan Produksi". Dengan terkelolanya elemen procurement, warehousing dan production pada rantai pasok menggunakan e-SCM, diharapkan tidak akan muncul permasalahan pengelolaan pada hulu rantai pasok. Dengan e-SCM yang terintegrasi keseluruhan data mulai dari bahan, barang, pemasok maupun proses produksi dapat dikelola dengan baik dan efisien.

Produk yang dihasilkan distro adalah produk berupa sandang (fashion). Kebutuhan akan produk ini menjadi kebutuhan pokok. Produk yang dihasilkan distro memiliki segmentasi pelanggan anak muda atau remaja sampai orang dewasa. Karakteristik segmen tersebut adalah dinamis dan cenderung mudah menerima perubahan. Perubahan tren menjadi faktor utama terhadap munculnya permasalahan kelebihan stok maupun kekurangan stok produk. Antisipasi terhadap kebutuhan produk untuk pelanggan adalah yang menjadi foktor pemicu untuk melakukan stok barang. Pelanggan akhir (end user) maupun pelanggan bisnis membutuhkan informasi ketersediaan stok barang dengan cepat dan akurat. Dari sisi perusahaan yang melakukan produksi sebaiknya melakukan proses perencanaan (planning) berdasarkan tren permintaan dan ketersediaan bahan. Hal tersebutlah yang menimbulkan permasalahan pengelolaan hilir pada rantai pasok.

Permasalahan dalam pengelolaan hilir pada rantai pasok dapat diatasi dengan menerapkan e-SCM. Data permintaan dan penjualan produk dapat dikelola dengan mengelola elemen demand management. Pada elemen ini fitur yang dapat diterapkan mulai dari "Pendaftaran Pelanggan", "Mengelola Pelanggan", "Mengelola Produk eCommerce", "Transaksi Penjualan", "Melihat Produk" sampai "Melakukan Pemesanan". Ketika pesanan telah sesuai maka selanjutnya dapat dilakukan pemrosesan pesanan penjualan dan pengirimannya. Elemen yang membahas proses tersebut adalah "Transport \& Distribution". Pada elemen tersebut dapat diimplentasikan dengan menjalankan use case atau fitur "Mengelola Pesanan Penjualan" dan "Mengelola Pengiriman 
Pesanan". Elemen planning seharusnya menjadi bagian yang tidak terpisahkan ketika membahas Supply Chain Management. Namun pada penelitian ini, dari kedua sistem yang dianalisa tidak terdapat fitur-fitur yang membahas pada elemen planning dalam supply chain.

\section{SIMPULAN DAN SARAN}

Berdasarkan penelitian yang telah dilakukan melalui perancangan, implementasi dan analisis dapat disimpulkan beberapa hal sebagai berikut: Sistem konvensional yang berjalan saat ini pada usaha distro, hanya cukup untuk menangani transaksi dalam skala regional saja. Dengan mengimplementasikan suatu sistem e-SCM diharapkan dapat meningkatkan efisiensi produksi distro dan mengefektifkan distribusi barangnya. ESCM dapat mengintegrasikan keseluruhan data pengelolaan distro terkait dengan manajemen rantai pasokan mulai dari hulu sampai hilir. ERZAP merupakan Enterprise Resource Planning (ERP) dan TRADEGECKO merupakan Inventory Management System (IMS). Dalam penelitian ini, fitur-fitur yang ada pada kedua sistem tersebut difokuskan pada kajian Supply Chain Management. Terdapat beberapa elemen supply chain yang tidak dimiliki oleh kedua sistem. Seperti misalnya elemen planning yang tidak ada pada ERZAP dan elemen planning dan production tidak ada pada TRADEGECKO.

Permasalahan pengelolaan pada hulu rantai pasok adalah pemasok tidak mendapatkan informasi mengenai kebutuhan bahan maupun barang. Permasalahan lainnya adalah pihak distro yang tidak memiliki informasi ketersediaan bahan maupun barang yang dibutuhkan. Permasalahan pengelolaan pada hilir rantai pasok adalah permasalahan informasi ketersediaan stok barang yang cepat dan akurat. Permasalahan lainnya dalam hal produksi harusnya melakukan planning, sehingga barang yang diproduksi dapat sesuai memenuhi kebutuhan pelanggan.

Saran yang dapat diberikan untuk pengembangan penelitian ini selanjutnya adalah dapat melakukan pengukuran kinerja supply chain dengan menerapkan model SCOR (Supply Chain Operations Reference). Untuk melihat kebermanfaatan penerapan e-SCM, pemilik distro dapat melakukan analisa terhadap perkembangan omset yang dihasilkan distro berdasarkan pengaruhnya dalam menerapkan e-SCM.

\section{DAFTAR RUJUKAN}

Abdurofiq, A. (2014). Menakar Pengaruh Masyarakat Ekonomi ASEAN 2015 Terhadap Pembangunan Indonesia. Jurnal Filsafat Dan Budaya Hukum, 1(2), 249-256. https://doi.org/10.15408/sjsbs.v1i2.15 43

KEMENKOP UKM RI. (2012).

Perkembangan Data Usaha Mikro , Kecil , Menengah ( Umkm ) Dan Usaha Besar ( Ub ). Retrieved from http://www.depkop.go.id/beritainformasi/data-informasi/data-umkm/

KEMENKOP UKM RI. (2013). DATA USAHA MIKRO, KECIL, MENENGAH (UMKM) DAN USAHA BESAR (UB) TAHUN 2012 - 2013. Retrieved from http://www.depkop.go.id/beritainformasi/data-informasi/dataumkm/?elD=tx_rtgfiles_download\&tx _rtgfiles_pi $1 \% \overline{5 B}$ Buid $\% \overline{5 D}=9$

Litman, T. (2013). Planning Principles and Practices. Retrieved from https://pdfs.semanticscholar.org/941f/ 2e27f2c9abeb204113a34c8bfcb5ea8 8ddd6.pdf

Pulevska-Ivanovska, L., \& Kaleshovska, N. (2013). Implementation of eSupply Chain Management. TEM Journal Journal, 2(4), 314-322. Retrieved from www.temjournal.com

Setyawan, I. N. Y., \& Marti, N. W. (2013). Sistem Informasi Kerajinan Lukisan Kaca Desa Nagapaha Berbasis Web. Jurnal Pendidikan Teknologi Dan Kejuruan, 10(2), 61-72.

Sorak, M., \& Dragic, M. (2013). Supply Chain Management of Small and Medium-Sized Enterprises. In DAAAM International Scientific Book (pp. 951-968). Vienna: DAAAM International. https://doi.org/10.2507/daaam.sciboo k.2013.59 